\title{
Forging Sharif Subjects
}

In 1906, a young woman named Sayyida Jamila moved to Delhi with the support of her uncle to acquire medical education at a madrasa linked to a women's hospital. Her relatives pressured her immediate family to stop her. They argued that only lower status/caste (ajlaf) women left the protected space of the home. For respectable (ashraf) women like Jamila, it was enough to acquire knowledge of the sharia (religious injunctions) at home. Jamila responded to this criticism through an article, which was published in Ismat magazine. ${ }^{1}$ She resisted her relatives' narrative by citing several sayings (hadith) of Prophet Muhammad and argued that it was incumbent upon both men and women to acquire knowledge (ilm); that there were two types of ilm-bodily and religious-both of which were necessary according to the Prophet. She explained that it was essential for women to learn medicine so that they could tend to other women in ways that male doctors could not. She also berated Muslims for falling behind in this endeavor, noting that other ethnic groups (quam) have continued to acquire broad education.

Jamila's story succinctly illustrates the competing notions of appropriate knowledges and educative spaces for respectable women that circulated at the turn of the twentieth century in colonial India. This period is marked by increasing anxiety on the part of the ashraf (singular, sharif) social classes, who had previously enjoyed privileges in the Mughal courts but after the entrenchment of the British rule were now struggling to preserve their social status. Women and their practices emerged as a prominent discursive space in and through which religious reformers, modernists, nationalists, and even women themselves contemplated their desired futures. This discourse was connected to concerns about women's mobility (Jamila had left her home), knowledges deemed appropriate for women (Jamila wanted 
to pursue education in medicine), and engagement in paid work (Jamila wanted to work as a doctor), which in turn had implications for their status as respectable (sharif) subjects. Thus, the nature of women's education-in particular, what should it be about, where should it happen, and toward what ends-became a topic of intense debate. In this chapter, I trace these ongoing discussions about women's education at the turn of the twentieth century in order to unpack concerns around social status, class, and gendered spaces. Specifically, I examine political speeches, advice texts, novels, and women's writings in Urdu periodicals. While I focus on the narratives of Muslim men and women, it is crucial to remember that these debates were shaped by the colonial experience, which I discussed in chapter 1.

\section{GENDER, SOCIAL CLASS, AND RESPECTABILITY}

During the early nineteenth century, Muslims were divided broadly into two social classes: the ashraf (distinguished/respectable) and the ajlaf (the low-born or common). ${ }^{2}$ The former often included members of the nobility, aristocracy, scholars, and the landed elites, and the latter, traders and artisans. These categories mapped onto Muslims who had migrated to India versus the local converts, with the ashraf being Muslims of foreign ancestry, particularly Arab, Persian, Turkic, and Afghan. Cultural elements such as dress, etiquette, aesthetics, familiarity with Persian and Urdu, and the art of elegant conversation marked a person as sharif.

The economic power of the ashraf, however, came under pressure as the British colonial state expanded in India. While earlier, the British had sought alliances with local rulers, after the rebellion of 1857 , they shifted to direct administration, which precipitated the decline in resources such as stipends, employment, and other privileges that ashraf Muslims had enjoyed. Furthermore, changes in inheritance laws and pensions/tributes left many families with limited resources. The British also created new educational institutions, which provided opportunities for upward mobility to groups that were previously excluded from the ashraf social class. Likewise, the establishment of the railway system proved opportune for traders who prospered. Hence, in the post-1857 context, we observe a reconfiguration of the social groupings, specifically a disaggregation of the ashraf into nobility (linked to the Mughal court), the "new ashraf," 3 and the rest of the population. According to South Asian historian Margrit Pernau, the "new ashraf" came to include scholars, landed elites, as well as enterprising traders and merchants. The nobility was increasingly viewed as irrelevant. One of the ways in which the new ashraf established their distinctiveness was through a redefinition of sharafat (respectability). To be sharif no longer meant being linked to an aristocratic culture; instead, sharafat was signaled through one's social practices, which included hard work, religiosity, and self-discipline. ${ }^{4}$

These trends were accompanied by a radical reconfiguration of urban spatialities under the British. Indian historian Faisal Devji elaborates on how the 
spaces where the ashraf men had exerted influence such as the administration, the courts, and the mosques, underwent extensive change under the British, reducing elite Muslim men's authority. ${ }^{6}$ For instance, the British instituted their own legal system, leaving only family law to be regulated by Muslims. Furthermore, since religion was privatized, the ulema were also beginning to lose their public authority. Against this reconfiguration of public spaces, focus shifted to the space of the home. Relatively unregulated in the past, the home now surfaced as comprising the potential to redefine Muslim identity and norms of respectability. It is precisely in this context that women were transformed from being seen as causing fitna (chaos), embodying uncontrollable sexuality, and not being appropriate for raising children, to becoming the upholders of familial morality, domestic managers, and mothers of future citizens. ${ }^{7}$ It was believed that women could be reformed through education, and in doing so, perform sharafat. Women's languages, religious practices, learning, relations with each other and with the opposite sex, mobility, and engagement with waged work, all came under intense scrutiny. In other words, women were brought into tighter circuits of control and surveillance. ${ }^{8}$

One element of this surveillance entailed reforming women's religious practices and bringing them closer to orthodox Islam. This in turn amplified the need to define and codify Islam, a task that proved to be extremely difficult, given the diversity of Muslims in colonial India. Since "customary law" was accepted as a legitimate source of sharia, there existed multiple stances on issues such as purdah, inheritance, and polygyny. However, customary practices were increasingly marked as un-Islamic by some Muslim reformers who advanced their own understandings about proper Islam. Hence, in this period we also observe an intense effort to codify Islam, one in which, alongside the ulema, the newly emerging trader/merchant classes participated as well by actively funding mosques, building schools, disseminating religious texts, and undertaking other pious endeavors. ${ }^{9}$

These contestations had real consequences, particularly for women from the nobility who had previously enjoyed active roles in the lives of their families as well as in political and economic domains. Family networks signaled social status and women had played important roles in cementing these networks through marriages and maintaining relations, including participating in rituals and festivals. Pernau notes that "the woman of the highest rank generally held uncontested sway in the women's quarters"10 and in relation to a young bride, it was the husband's mother, rather than the husband himself, who held authority. Measures were also in place to ensure upper-class women's financial security through property and exclusive use of the dower (mahr). Given the exclusion of men from women's spaces, women had developed a unique form of speech, known as begmati (ladies' language). This language included figurative terms and expressions that were linked to women's everyday practices. ${ }^{11}$ The broader shifts that took place during colonial rule, including changes in property ownership and inheritance, led to many transformations in women's roles. 
A popular didactic novel, Mirat-ul-uroos (The Bride's Mirror; published in 1869) written by Nazir Ahmed (d. 1912), succinctly illustrates these dynamics. This novel also outlines how a broad range of women's actions came to be linked to familial respectability. In the novel, Nazir Ahmed employs the characters of Akbari and Asghari, two sisters married to two brothers, Akil and Kamil, as foils against each other to explicate the performance of an ideal educated Muslim female subjectivity. Asghari has elementary reading and writing skills, is an expert at household management, and abides by "proper" Muslim practices-that is, she does not engage in superstitious customs or excessive rituals. Due to her training and intelligence, she is able to create a happy and harmonious home for her husband and in-laws. Ahmed narrates several episodes where Asghari's ability to read and write enables her to forestall inconvenient situations. Over time, Asghari goes on to establish a successful madrasa at her home for the girls of her neighborhood. Even though etiquette restrains her from charging her students fees, she is able to extract personal benefit from the institution, including securing a good marriage proposal for her sister-in-law, using monies made from selling students' products to decorate the rooms where she holds classes, as well as utilizing gifts from students to maintain relations in the neighborhood.

In contrast, Asghari's older sister, Akbari, is unable to maintain her household even though her husband makes a decent income. She is impulsive and does not preserve class boundaries. For example, she mingles with the rich as well as the poor, and shares personal details with them. To mark such cross-class familiarity as inappropriate for sharif women, Ahmed shows that Akbari gets swindled by a hajjan (a women who had recently returned from performing the hajj/pilgrimage). Akbari neither has the acumen to stay away from such charlatans, nor the basic literacy skills to detect their frauds. This is in contrast to Asghari, whose social aloofness and distant attitude toward women from lower social classes is praised by Ahmed. Asghari intentionally avoids contact with women from non-sharif backgrounds and invites only sharif girls to her home-based madrasa. Clearly Akbari's and Asghari's actions articulate their social class and status, securing or unraveling claims to sharafat.

In Asghari, then, we find a performance of what Ahmed deems to be an ideal sharif subject, one who reproduces her own and her family's social standing. And, it is Asghari's education that enables her to manage her household competently, as opposed to Akbari, who exposes herself and her husband to extreme hardship because she does not relate to the world in a way that an educated woman would. Ahmed goes into detail about the type of education that Asghari received. Her training includes the study of the Quran, literacy (in the languages and mathematics), skills (hunar), etiquette (saleeqa), proper religious practices, and household management (khana-dari). This broad education takes place within the confines of the household. Asghari, in turn, imparts similar training to other girls from the neighborhood. In addition to reading skills, she teaches them duniya ka kaam 
(affairs of the world), which includes skills necessary for managing a household (such as sewing, cooking, dyeing clothes, and organizing ceremonies). She also teaches Muntakhab al-hikayat (a selection of didactic stories) for her students' entertainment. Ahmed advocates this kind of education for women if the Muslim quam intends to reclaim its status.

As alluded to earlier, Mirat-ul-uroos was written in a context when the Muslim aristocratic families were undergoing radical changes as a consequence of losing their prior positions of authority within the Mughal administration. The British increasingly excluded Muslims from the army, revenue collection, and political offices, and the rise of Hindus within those institutions left elite Muslims in a real and imagined precarious position. It also put pressure on the opportunities afforded to women for education. In the preface of Mirat-ul-uroos, Nazir Ahmed notes that even though it is not a custom in India for women to read and write, many women from sharif families especially in large cities know how to read the Quran and other texts. Indeed, Ahmed's own family in Delhi was one such family. Since sharif Muslim women practiced seclusion, they were often educated at home by their fathers, brothers, and/or visiting ustanis (female teachers), who were usually the wives and daughters of the maulvis (religious functionaries). However, with the deteriorating economic position of ashraf Muslims in North India, limited incomes were available to retain teachers. This led to a severe decline in the ability of Muslims to hire female teachers at a time when their demand was high. ${ }^{12}$ In addition, while there had existed an extensive system of private and public patronage as well as endowments (waqfs) for boys that facilitated the establishments of maktabs and madrasas, the regulation of waqfs by the British administration severely limited the availability of funds for such educative enterprises. All in all, the local systems of knowledge transmission in place for both boys and girls came under extreme strain, as the colonial administration entrenched itself in India. These trends were accompanied by explicit and implicit policies by the British administration to direct funds toward English education, ${ }^{13}$ and to strengthen English as the language of the government. ${ }^{14}$ That Persian language was abolished as the language of the administration by the British in 1837 led to further economic marginalization of many ashraf Muslims.

Against this background, the genre of didactic novels in Urdu emerged as a critical site for educating Muslim youth, especially young women, of which Mirat-ul-uroos was one of the earliest. ${ }^{15}$ Nazir Ahmed, for instance, notes in the preface that he wrote Mirat-ul-uroos as an advice text for his own daughters in order to reform their thoughts and improve their habits. Ahmed himself belonged to the socioeconomic group that had to professionalize in order to secure employment and resources under the raj. Hence, his writings seem to represent the active efforts of Muslims of the "new ashraf" to reproduce/sustain their privilege by simultaneously distancing themselves from the nobility and becoming more enterprising. Two thousand copies of his book were acquired to 
be distributed to English schools; a hundred thousand copies were sold over the next few years. ${ }^{16}$

Nazir Ahmed's text was one articulation among a cacophony of ideas about education for women and girls that emerged from the mid-nineteenth century through the turn of the twentieth century. Pointedly, while there was consensus around reforming women, there were differences particularly in relation to the content and space for women's education. These differences can be mapped onto social class as well as varying assumptions about women's social roles. Significantly, as this chapter will show, women too participated in this discussion. However, before delving into women's writings, I will review the dominant elements of the debate on women's education shaped largely by male social reformers. I am less concerned about providing a comprehensive overview and more interested in tracing the contours of this debate. Therefore, I center select Muslim reformers and their writings in order to represent some elements of the ongoing public discussions. I have chosen reformers who belonged to different religious interpretive traditions, had different levels of association with the British, and differed in their views about women's education.

\section{WHAT SHOULD WOMEN KNOW?}

Muslim social reformers differed on which knowledges were necessary for women, as well as the spaces where women could acquire these knowledges. ${ }^{17}$ These perspectives, often advanced by male social reformers, set the contours of the public discussion on this topic. Female authors writing in periodicals or speaking at women-only political gatherings were in some ways engaging with, responding to, and critiquing what their male counterparts were calling for. Broadly, there were those who believed that all kinds of knowledges that were considered appropriate for boys were relevant for girls as well; those who thought that knowledges imparted in English schools were out of the question for sharif girls and that Muslims had to devise their own institutions and curricula for them; and others, who believed that elementary literacy skills acquired at home were adequate for girls. These different perspectives on what knowledges girls should acquire appear to reflect the reformers' visions of how the ashraf could maintain their status in what was seen as an increasingly precarious environment.

The prominent Muslim scholar and education reformer Sir Syed Ahmed Khan (d. 1898) argued that it was not necessary to invest in the public education of women. While of the opinion that Muslims needed to study the English language and western sciences in order to recover their status in India, Sir Syed emphasized the education of boys over girls. Sir Syed was the leader of the Aligarh Movement, which sought to reinvigorate Muslims in the subcontinent in the aftermath of the decline of the Mughals and the War of Independence of 1857. Much of his effort was aimed at establishing educational institutions. In 1864, he founded the Scientific 
Society and in 1875, a school in Aligarh called the Muhammedan Anglo-Oriental College, which in 1911 became the Aligarh Muslim University. While Sir Syed advocated for a broad education for men, he did not think that education beyond the religious sciences was necessary for girls, or that separate schools had to be established for them. Sir Syed subscribed to the "trickle-down theory," ${ }^{18}$ whereby educated men would be able to educate their wives, sisters, and daughters at home, who in turn might educate their sons. That was indeed the norm in shariffamilies. The training of the fictive character of Zubayda Khatun, featured in prominent Indian Muslim poet and writer Altaf Hussain Hali's (d. 1914) Majalis-un-nissa (Gatherings of Women), gives a glimpse into women's education at home: "By the time I was thirteen, I had studied the Gulistan and Bostan, Akhlaq-e-muhsini, and Iyar-e-danish in Persian, and in Arabic the necessary beginning grammar, in arithmetic the common factors and decimal factors and the two parts of Euclid's geometry. I had also studied the geography and history of India, and had practiced both naskh and nasta'liq calligraphy and could copy couplets in a good hand. At that point, my father began to teach me two lessons a day. In the morning we read Rimiya-e-sa'adat and in the evening Kalila wa dimna in Arabic."19

Zubayda Khatun had been educated enough that she was able to train her son in elementary Urdu, mathematics, and the Quran before sending him to school. In her case, then, education was linked with personal fulfillment and some contribution to the family. It is precisely due to this reason that Sir Syed said, "the present state of education among Muhammadan females is, in my opinion, enough for domestic happiness, considering the present social and economic condition of the life of the Muhammadans of India." ${ }^{\circ \circ}$ Furthermore, Sir Syed was keenly aware of the hypocrisy of the colonial critique of Muslim women's position in India. On one occasion, he noted that although, "England greatly favors the freedom of women, yet when its laws are examined, it is obvious that the English consider women quite insignificant, unintelligent and valueless." ${ }^{21}$ He explained that in England women cannot "hold responsibility for any legal instrument" without the husband's consent and that prior to 1870 property gained through inheritance as well as its profits belonged to the husbands. ${ }^{22} \mathrm{He}$ further observed that while there may be "excess" of purdah in India, there are other kinds of excesses in Europe as well. Sir Syed represents that moment in the history of Indian Muslims when they were beginning to lose their privileged positions. Sir Syed could still imagine sharif men as being responsible for the development of both the private and public spheresthe masters of both domains - if they acquired western knowledges. Indeed, in Altaf Hussain Hali's narrative, Zubayda's son is advised to engage with classical sciences only to the extent that they are helpful practically. Instead he is to acquire English, the language of the new rulers. ${ }^{23}$

By the late nineteenth and early twentieth centuries a wave of social reformers emerged who adamantly believed that educating women at home, government schools, or Islamic schools was necessary in order to strengthen the Muslim quam 
and harmonize relations within the family. Education, they believed, would make women better wives and mothers, and enable them to take over the management of their homes as men left to look for work under the new administration. This is a distinctly new subject-woman as the home manager, as a companion, and as a child-rearer-which came into being as a consequence of the rapidly changing political and social contexts of Muslims in North India. Some reformers even made allowances for women to engage in paid labor to be able to support their families economically. These different subject positions called for different kinds of knowledges and spaces for the educative enterprise.

To understand the prevailing conditions of ashraf women's education we can consider Syed Shamsuddin ibn Miansaheb Qadri's short pamphlet entitled, Risala talim-niswan (Pamphlet on Women's Education), published in 1895. Qadri, was the deputy education commissioner/inspector and his writings provide a glimpse into some of the emergent concerns around women's education. The author begins by lamenting the current conditions of the quam, and nostalgically recalls the times when his ancestors (Muslims) had high status in ulum wa fanun (knowledges and skills), ${ }^{24}$ which in turn signaled the high status of Islam. He goes on to argue that the welfare of nations depends on the talim wa tarbiyat (education and nurturing) of both men and women. The Risala is composed of several didactic stories. It tells us about the efforts of Zeb-un-Nissa, who used to write the alphabet on different toys so that her daughter could learn it while engaging in play. It narrates the story of a girl, Husunara, whose parents did not educate her even though they were welloff. Husunara was later married to an ilm dost (friend of knowledge), who upon finding out that his wife is not educated expresses amazement. ${ }^{25}$ The author notes that the hearts of educated and uneducated people often do not find harmony with each other. ${ }^{26}$ In fact, "for an uneducated woman to be in an educated man's house is hell for him in this world." ${ }^{27}$ We clearly see emergent ideas about companionship and happiness in marriage in relation to women's education. ${ }^{28}$ These ideas get taken up by other reformers as well. In addition, the notion that women are bearers of civilization is also salient in the Risala. Qadri argues that it is important for women to be educated because if men are uneducated then the effects of that remain limited to them but if women are baywakoof (foolish) then their children suffer as well. ${ }^{29}$

By the turn of the twentieth century, within sharif circles, the question around women's education was no longer one of whether or not women should have an education. It revolved mostly around the knowledges required for women and the ideal location to transmit them. Mumtaz Ali (d. 1935), a prominent advocate of women's education and founder of the women's journal Tehzib-e-Niswan, called for a broad education of women, which included the study of religious sciences as well as reading and writing. In his work Huquq un-niswan (Women's Rights), published in 1898, he argued that since God had given women equal intellectual faculties as men, they deserve access to the same education. ${ }^{30} \mathrm{He}$ countered his 
critics, who believed that too much education would lead to vulgarity in women by noting that any education that did so could lead to the same vulgarity in men as well. ${ }^{31} \mathrm{He}$ then went on to present a strategy for expanding women's education through establishing a women's newspaper and publishing a list of novels suitable for study by women. ${ }^{32}$ He believed that an education would enable women to develop the skills necessary for becoming better, more interesting companions for their husbands. His articulation for the need for companionship within marriages seems to be premised on the complementarity between the male provider and female housewife, which led him to prioritize women's roles as wives and their ability to fulfill their domestic responsibilities. Women, hence, needed to acquire knowledges that could help them become domestic managers and interesting companions. Mumtaz Ali's is a distinctly elite position, which assumes division of labor along gender lines. Such divisions were not possible for Muslims from lower economic classes. The social reformers who focused on those social classes, hence, elaborated a different vision for women's education. In fact, concern for women from low-income social classes is most visible in the calls for education advanced by another prominent leader, Sir Sultan Mahomed Shah Aga Khan (d. 1957).

Sultan Mahomed Shah Aga Khan III was born in Karachi, in today's Pakistan, on November 2, 1877.33 He became the forty-eighth imam of the Shia Ismaili Muslims at the age of eight on the passing away of his father, and went on to establish himself as an influential political leader, not only in colonial India but also on the international scene. In addition to facilitating the establishment of the Muhammadan Anglo-Oriental College at Aligarh, he worked closely with the leaders of the Pakistan Movement as well as the British administration to secure the recognition of Muslims as an independent political entity. In 1902, he was appointed to the Legislative Council set up by Lord Curzon, and in 1906, he was elected as the first president of the Muslim political organization, the All India Muslim League. He remained active on the Indian political front throughout his life but over time increasingly took on international policy-oriented tasks, including serving as the president of the League of Nations for a brief period.

While of similar views as Mumtaz Ali, the Aga Khan argued for women's education, not only for the purpose of discharging responsibilities in the domestic sphere as bearers of civilization, but also for becoming economically independent from their male relations and acquiring personal happiness. ${ }^{34}$ In his text India in Transition, published in 1918, the Aga Khan notes that one of the reasons due to which reforms for women's progress had been slow was because they had been motivated by the end purpose of service to the other gender and not for women themselves. He suggests that "the constant argument has been that of the necessity for providing educated and intelligent wives and daughters, sisters and mothers, for the men ... the time has come for a full recognition that the happiness and welfare of the women themselves, must be the end and purpose of all efforts towards improvement." 35 In fact, with respect to his own followers, the Ismaili Muslims, 
he noted, "I am trying to guide our young women's lives into entirely new channels. I want to see them able to earn their living in trades and professions, so that they are not economically dependent on marriage, nor a burden on their fathers and brother[s]."36 A Muslim leader with strong ties to the British administration and extensive exposure to social movements in Britain and America, the Aga Khan argued for universal and compulsory access to education for the masses, and worked with the British government to instate legislation that would make primary education compulsory for both boys and girls. ${ }^{37}$ As the spiritual leader of Shia Ismaili Muslims, who were a minority interpretative tradition in Islam and were primarily from the non-ashraf classes, the Aga Khan was concerned with a population that was often poor and did not have the resources to partake in homevisitation or home-based educative efforts. ${ }^{38}$ We can, thus, assume that it made most sense for the Aga Khan to call for changes in the government's policies that would affect the ashraf and non-ashraf alike.

Relatedly, since the Aga Khan hoped to improve the economic well-being of his followers, he welcomed women's participation in economic activities. He, therefore, did not want education for girls to stop with basic literacy or elementary religious knowledge, and emphasized that "all knowledge in the world should be open to girls." 39 To increase his female followers' mobility, he banned the purdah, noting that "the free social and intellectual part played in the life of Arabia by Imam Hussain's daughter, Sakina, and by the daughter of Talha and the great grand daughters of Khalifa Abu Bakar can be contrasted with the position of women in the 19th century".40 In his Memoirs, published in 1954, he notes, "in my grandfather's and my father's time the Ismailis were far ahead of any other Muslim sect in the matter of the abolition of the strict veil, even in extremely conservative countries. I have absolutely abolished it; nowadays you will never find an Ismaili woman wearing the veil."41 In this regard the Aga Khan was indeed an outlier when compared to his peers; even Mumtaz Ali, while advocating the toning down of the strict purdah observed by Indian women, ${ }^{42}$ was neither in favor of its abandonment nor for the integration of women in the public school system. What we have, then, is a reformer whose investment in a particular social class of Muslims moved him to articulate a vision of education that led to greater mobility for his female followers. However, while condemning purdah among his followers, the Aga Khan was careful not to fall into the Orientalist trap of seeing purdah as a social ill, as the British did. In a letter to the Times on August 8, 1919, he disagrees with Lord Southborough's denial of suffrage for Indian women on the grounds that Muslim women in purdah would not be willing to go to the polling booths. He argues that "purdah ladies go into the law and registration courts all over the country, and give evidence in relation to the transfer of property," ${ }^{\prime 3}$ and that women's electoral franchise is an issue of justice.

In contrast, another key Muslim reformer, Ashraf Ali Thanawi (d. 1943), of the Deoband madrasa (funded by the "new ashraf"), ${ }^{44}$ was unwilling to compromise 
on the prevalent practices of seclusion and, hence, argued for increasing women's basic literacy skills just enough so that they were able to communicate with the outside world and engage in the practice of religion. Thanawi was an influential religious scholar, whose juridical as well as other writings provide a glimpse into this scholarly class's efforts to retain their authority in a changing political context. ${ }^{45}$ He wrote numerous texts, one of which entitled, Bahishti zewar (Heavenly Ornaments), published in 1905, is considered one of the most influential Urdu books in Muslim South Asia, with the highest number of editions. ${ }^{46}$ The text introduces women to Islamic norms and provides a curriculum of sorts, so that women could address their educational needs without leaving the zenana. The text is also a discursive effort at constructing women as the guardian of Islamic morality, and clarifying what it meant to be an educated Muslim woman.

Bahishti zewar calls on women to reform their corrupt/superstitious practices and provides detailed guidance on religious rituals, duties, laws, and etiquette. Thanawi elaborates on acceptable relations between men and women, nuances of public transactions such as loans, contracts, and property ownership, and the rights of men and women according to Islamic law, among other things. He also makes space for women to undertake certain economic activities (such as making mango pickles), which could help them secure some economic independence. He employs the text to impart basic literacy skills to his female readers as well. Recognizing that his text was of an introductory nature, Thanawi encourages women to study advanced religious sciences. However, he does not propose a plan for women to accomplish this. As noted earlier, the zenana-school system was limited in what it could offer women in terms of educational enhancement. Women, therefore, would have had to leave the zenana in order to obtain the advanced knowledges that Thanawi proposed. However, by showing a strong preference for seclusion, Thanawi limited his own proposal. While Bahishti zewar deals with women's issues, according to Islamic studies scholar Muhammad Qasim Zaman, its broader function seems to be to establish the ulema's authority to guide Muslims in a time of extensive religious contestation. ${ }^{47}$ Thanawi's text betrays anxieties around new forms of femininities that reformers such as Nazir Ahmed, Mumtaz Ali, and the Aga Khan were advocating; in fact, Thanawi lists Nazir Ahmed's book as one that should be banned. His is, then, an effort to provide an alternate figuration of educated femininity that could respond to the changing social context while still maintaining the religious practices that he deemed to be appropriate.

If one analyzes the different knowledges that were deemed appropriate for women from the perspective of the kinds of subjects that they sought to produce, it becomes clear that they are informed by different conceptualizations of societal needs and women's roles in fulfilling those needs. The curricular proposals put forth by Thanawi, Sir Syed, and Ahmed call for an educated subject whose education is to advance familial, and to some extent communal, interests. It is a subject who understands her responsibility to reproduce familial respectability 
and willingly pursues it. While Thanawi opens up space for women to acquire specialized knowledges - religious knowledges being historically restricted to elite Muslim men-and, hence, appears as egalitarian, his proposals are delimited by his preference for seclusion and lack of institutionalized spaces for Muslim women to acquire said knowledges. The Aga Khan and Mumtaz Ali, on the other hand, call for knowledges that might allow for the recognition of a woman's personhood. They imagine a subject who pursues education for her interests, thinks about her own economic independence, and knows and fights for her rights (after all, Mumtaz Ali's seminal text was entitled Huquq-un-niswan, or Women's Rights). This is especially the case in relation to the Aga Khan who gave a range of directives to his followers in order to enhance their economic welfare. Education, then, was to produce a sense of individuation in this subject and a discernment that might allow her to balance familial and communal interests with personal desires.

As I have suggested earlier, the concerns of the male reformers seem to be inflected by their own social class as well as the social groups for which they advocated. Whereas the Aga Khan may have called for women's education to increase their independence from patriarchal control, Mumtaz Ali's call for educated wives as better companions reformulated patriarchal control. These overlapping, yet distinct, educated subjectivities are what become a point of negotiation at the turn of the twentieth century. Women, too, participated in these discussions-an aspect that has remained understudied thus far. My examination of women's writings shows that the gender of the authors did not lead to radical departures; women's writings, thus, are part of the same knowledge regime.

\section{WOMEN'S WRITINGS}

While "Muslim women" appear as central objects of concern and reform in both colonial and nationalist discourse, official histories of Muslims in India often do not include women's own voices. ${ }^{48}$ The dominant image of the Indian Musalman woman of the eighteenth and nineteenth centuries is one of being uneducated, silent, and secluded. However, as the evidence below will show, Muslim women were not silent objects of reform projects but actively engaged in them. Unlike their male counterparts, however, their work was often featured in periodicals, dairies, reformist literature, interviews, letters, and pamphlets-writing products that have not been considered worthy of preservation. These texts, however, give us important clues about the political and social culture of the period, as well as the dominant idioms in and through which life was lived and imagined.

Women's periodicals began to appear in many languages in colonial India around the mid-nineteenth century. These periodicals were part of a broader range of written materials, such as didactic novels, pamphlets, and dastaans (stories) that were increasingly becoming available due to the accessibility of the printing press. While male social reformers established most of these periodicals at the time, 
many took care to note the valuable partnership, sometimes co-editorship, of their wives or other female relatives. That these periodicals provided an opportunity to both men and women to educate women is evidenced by their public goals as well as their titles. For example, Mu'allim-i-Niswan means "Women's Teacher" and Tehzib-e-Niswan can be translated into "Women's Cultural Upbringing." While often men also wrote in the periodicals (sometimes even writing as women), the periodicals did provide women an avenue to engage with each other in multiple ways. Through the periodicals women obtained information about the activities of the British administration and Muslim social reform movements; shared childrearing and domestic management practices; provided interesting leisure reading materials; explained cultural practices of women from other parts of the world; and practiced their writing skills and shared personal news. In the periodicals women also expressed their views on the then contested topics such as purdah/ veiling, marriage, polygamy, right to vote, Age of Consent laws, women's dress, and education.

While this book focuses on Urdu periodicals and novels, women's writings were emerging in other languages too. In the context of colonial India, for instance, Padma Anagol has analyzed women's press in the Marathi language to illuminate the ways in which women put forth their critiques of Indian society and gender relations. ${ }^{49}$ Anagol notes, "writing gave women the opportunity to recast themselves as modern women, rather than being recast by men, thereby preparing themselves for the rapid changes brought by the colonial world" (original emphasis)..$^{50}$ She argues that it is crucial to explore the agency of women as a group in order to correct dominant portrayals of the historical moment. Other scholars have chosen to focus on individual women's lives. For example, Tapan Ray-Chaudhuri and Geraldine Forbes examine the memoirs of Haimabati Sen, a female doctor who challenged medical hierarchies, ${ }^{51}$ Tanika Sarkar has written about the first Bengali autobiographer, Rashsundari Debi, ${ }^{52}$ and Elora Shehabuddin has explored the work of Rokeya Hossain and her fictional text Sultana's Dreams. ${ }^{53}$ Sarkar has also explored women's periodicals from Bengal to examine why Muslim women were written out of official Indian nationalist histories in the first place. ${ }^{54}$ She argues that Brahmo/Hindu women often constructed Muslim women as the "backward" other to bolster their own image as "liberated/modern": "representation of Muslim women as 'backward/victimised' were intimately related to the production of the category modern 'ideal Indian woman' as Hindu, upper caste/middle class and the category 'Muslim' as predominantly male, violent, dissolute and 'medieval' in late colonial Bengal." ${ }_{55}$

Likewise, scholars concentrating on the Middle East have also found it productive to engage with women's writings in the periodicals. Marilyn Booth, for instance, examines over five hundred biographies published in Egyptian newspapers and magazines between 1892 and 1949 to highlight women's participation in negotiating modernity and nationalism. ${ }^{56}$ She argues that by examining the 
biographies, we can gain insights into "what women were doing, not simply to hear the oratory of male intellectuals debating 'women's status." 57 Likewise, Beth Baron's work on women's periodicals published in Egypt at the turn of the twentieth century also shows the dynamism between producers and consumers of early women's press..$^{8}$ She shows how the new literary medium was a productive platform for a voracious readership to interact with each other and with editors. My work, with its focus on North Indian Muslim women's journalistic writings in Urdu, then, adds to this scholarly tradition.

\section{Women's Magazines in Urdu}

The earliest women's periodicals in the Urdu language are Akhbar-un-Nissa, which was issued in 1887 under the leadership of Sayid Ahmed Dehlavi, and Mu'allimi-Niswan, published in 1892 by Maulvi Muhibb-e-Hussain. I was unable to find any issues of these two magazines. However, the third major periodical, Tehzibe-Niswan, issued in 1898 under the editorship of Sayyid Mumtaz Ali (1860-1935) and Muhammadi Begum (1878-1908) from Lahore, has been preserved in private collections, which I was able to obtain. The next major, albeit short-lived, periodical was Khatun, published from 1904 to 1914 from Aligarh under the leadership of Shaikh Abdullah (1874-1965) and his wife, Wahid Jahan (1886-1939), although the former was much more involved as Jahan took up the responsibilities of administering a girls' Normal School and then a hostel. Parda Nashin, edited by Mrs. Khamosh, was published in 1906; Ismat followed in 1908, published from Delhi by Rashid al-Khairi. Ismat is the only magazine from this time that has survived to the present time.

During the early decades of the twentieth century, an increasing number of periodicals began to be published under the editorship of women. Sharif Bibi, edited by Fatima Begum, in 1910; Zillus Sultan, which was the official journal that expressed the views of Sultan Jahan the Begum of Bhopal, edited by Muhammad Amin Zuberi in 1913; An-Nissa, edited by Sughra Humayun Mirza, from Hyderabad, in 1919, who also went on to publish Zeb-un-Nissa from Lahore in 1934; and, Hamjoli, published in the 1930 s under the editorship of Sauida Begum Khwishgi. The literary landscape thrived, with women not only taking up editorships but also authoring the majority of the articles in these periodicals. Soon after publishing the women's periodicals, both Mumtaz Ali and Rashid al-Khairi set out to publish a periodical explicitly for children and girls_-Phul (for children) was published by the former in 1910 and Bannat (for girls) by the latter in 1927. Rashid al-Khairi also published a journal entitled Tamaddun, aimed at men with the objective of changing their views about women's education. Tamaddun, however, was short-lived, from circa 1911 to 1916.

In this chapter I make the early issues of Tehzib, Ismat, and Khatun the primary object of my inquiry, given their prominence. South Asian historian Gail Minault has called these three periodicals the "the big three"59 of the Urdu language. She also argues that "for the study of the lives of middle class Muslim women in purdah 
and movements for their social and educational reform, women's magazines in Urdu are essential." ${ }^{\prime}$ The prominence of these periodicals was confirmed during my interviews with librarians at the University of Karachi, Mushfiq Khawaja, Bedil, and the University of Punjab. Locating these magazines has been difficult as archival preservation efforts in the past often ignored women's writings. ${ }^{61}$ Most issues are in private collections or, in some cases, at university libraries. I was able to secure a large number of issues by visiting public and private libraries in Pakistan during the summer of 2015. Specifically, I review Tehzib issues from 1906 (earliest available issues) to 1913, Khatun issues between 1906 (earliest available issues) to 1914, and Ismat issues from 1910, 1911, and $1919 .{ }^{62}$

In addition to women's journalistic writings, I also draw on two didactic novelsSughar beti (1905), and Sharif beti $(1908)^{63}$-and a biography, Hayat-e-Ashraf (1899), written by a pioneer female editor and writer, Muhammadi Begum. I bring them into dialogue with Mirat-ul-uroos (1869), by Nazir Ahmed, discussed earlier. These texts explicitly set out to do the pedagogical work of delineating ideal performances of Muslim womanhood and girlhood. While Nazir Ahmed's work has been discussed extensively, Muhammadi Begum's writings are still understudied since her work has not circulated in the same ways that Nazir Ahmed's has. Engaging with these novels enables me to elaborate key issues of the time and explore how literature partakes in establishing dominant regimes of truth.

\section{Tehzib-e-Niswan, Khatun, and Ismat}

Tehzib-e-Niswan (hereafter Tehzib), a weekly, was first published in 1898 in Lahore and was edited by Sayyid Mumtaz Ali and Muhammadi Begum. Both had established themselves as pioneers in thinking and writing about women's education and reform. Mumtaz Ali was a younger contemporary of Sir Syed Ahmed Khan, and it was known that Sir Syed did not completely agree with his views about women. In fact, Mumtaz Ali waited to publish his book, Huquq-un-niswan, until after the death of his mentor. ${ }^{64}$ Mumtaz Ali was educated at the Deoband madrasa and English-medium schools, an educational trajectory that would become increasingly common for many ashraf men. His wife, Muhammadi Begum, was educated at home, where she learned to read the Quran and keep household accounts, develop her Urdu language abilities, and acquire the domestic management skills of sewing and cooking. ${ }^{65}$ She was a prolific writer and, in addition to several short stories, wrote books on poetry, cooking, and housekeeping. She is undoubtedly one of the earliest Muslim female public writers in the Urdu language.

Tehzib was published with the explicit purpose of providing reading material for women. It included a diverse range of writings-articles discussed etiquette, relations with in-laws and husbands, childcare, housekeeping, recipes, news about parties, and announcements about upcoming events such as fundraising drives. Authors also expressed their opinions on ongoing debates such as purdah, polygamy, and wasteful expenditures at weddings. The periodical adopted language that 
would be comprehensible to women who had elementary reading skills. Tehzib's weekly format encouraged conversations among women. The letters to the editor offered another space for women to communicate with each other, seeking or offering advice, voicing opinions, or simply sharing personal news with their behnain (sisters). Tehzib, then, allowed for the emergence of a transregional community of sharif or tehzibi behnain (respectable or cultured sisters). Over time, Tehzib also published news about women's conferences and reproduced speeches. The journal remained active through 1949 under the leadership of various editors, including women.

Khatun was published from Aligarh between 1904 and 1914, and was edited by Shaikh Abdullah, the then secretary of the women's education section of the All India Muhammadan Education Conference, ${ }^{66}$ and his wife, Wahid Jahan. Abdullah founded the journal as the voice of the All India Muhammadan Education Conference. The journal, therefore, provided a review of the activities of the Conference, including speeches, news of committees on women's education sponsored by the government, and information about other conferences and rallies. It had the explicit purpose of improving the landscape of women's education in addition to providing high-quality literature for women to read. ${ }^{67}$ Its editors wanted to encourage a rigorous conversation about women's education, which included sharing their own views about how women's education could be institutionalized as well as the resources that were needed for this endeavor. Every issue of the journal opens by clarifying the purpose of the journal, specifically that it seeks to "spread education among women and to engender a knowledge-oriented disposition in educated women." ${ }^{38}$ In an article appearing in Khatun published in 1906 the editors note that this endeavor will not be successful without men's attention, and the magazine thus highlights for men the need for women's education and the drawbacks of not attending to it. ${ }^{69}$ Khatun imagined an audience that was already relatively literate, and therefore, did not make the concessions around writing style that Tehzib did. In addition, it envisioned its audience to be involved in politics and/or belonging to the social classes that had resources to raise funds for women's education. These characteristics, at the turn of the twentieth century, were shared primarily by ashraf men who were often the patrons of the Muhammadan Education Conference. Hence, the journal did not shy away from including writings by men for men on the topic of women's education. In fact, Shaikh Abdullah's editorials are one of the key spaces where we learn about the contemporary efforts for women's education.

Khatun, thus, was one of the key sources for me to learn about the British administration's efforts (or lack thereof) for Muslim women's education as well as the efforts of the Muslim ashraf classes. For example, the third volume of Khatun, published in 1906, provides a glimpse into the earliest efforts toward the institutionalization of women's education. Readers who needed female teachers had access to free advertisements; ${ }^{70}$ profits from the journal's sale were used to create 
scholarships for poor and orphan girls; and the female readers were urged to purchase the journal as a form of self-help. Early issues of Khatun include a large number of calls for funding girls' schools and feature the names of those who donated funds or in-kind support for women's education. Book reviews and serialized stories were also included in the journal. ${ }^{71}$ Altaf Hussain Hali's famous poem "Chup ki daad" (Justice for the Silent) was first published in Khatun in 1905.

Ismat, a monthly magazine, was issued from Delhi and is the only magazine that is still published in present-day Pakistan. Its first issue appeared in 1908, under the editorship of Rashid al-Khairi, a social reformer who also published extensively on the topic of women's education and rights in the form of didactic novels and fictional stories. Al-Khairi studied up to matriculation at the Delhi Anglo-Arabic School and was related to the well-known social reformer, Nazir Ahmed..$^{2}$ The cover of Ismat outlines that it is aimed at sharif hindustani bibiyan (respectable Indian women). The magazine featured serialized stories, editorials, commentaries on news, short articles, recipes, embroidery patterns, letters to the editor, poetry, and announcements for new books. While al-Khairi was the primary editor until his death, some issues were edited with Sheikh Akram and Mrs. Sheikh Akram as well..$^{73}$ Ismat's language was conversational, much like Tehzib's.

I view these periodicals (journalistic writings) as cases that give insights into the fractured production of the ideal womanhood. In other words, while the male social reformers-whose writings had greater circulation than women's writings-constructed ideal female educated subjects, such discursive productions inevitably erased the diversity of women's lived experiences. Attending to women's magazines sheds light on the kinds of contestations and negotiations that male-produced models created in women's literary cultures. Here we find that women often had multiple views on the topic of education, and intensely debated the appropriate knowledges, purposes, and spaces for education. The differences often emerged from women's divergent socioeconomic backgrounds. This is not to say that women departed radically from male social reformers' views. That, in fact, is not the case. What these periodicals, however, do show is the process of the very making of the educated subjects who were the object of the male social reformers' concerns. It shows that the production of the educated, sharif subject was not inevitable or straightforward. It was discussed and debated, and sometimes even rejected, by women. Thus, exploring the understudied genre of women's writings in Urdu periodicals helps to understand that women were not silent objects of reform projects but actively engaged with them.

\section{A CONVERSATION AMONG ISMATI BEHNAIN}

As noted earlier, in most cases, the debates around Muslim women's education were initiated by men and were aimed at women. Khatun, for instance, includes a plethora of evidence for this. Many of the articles are written by Shaikh Abdullah, 
who, as the secretary of the women's section, was at the forefront of attempts to establish schools for girls and provide training to female teachers. Likewise, Rashid al-Khairi also stressed reforms for women through his writings. In many cases, male reformers called on other men to advance reforms for women. For example, in Ismat, al-Khairi issued a call to Muslim preachers to take up the task of advocating for women to improve their lives. ${ }^{74}$ In elaborating the rational for establishing Tamaddun - the magazine aimed at men-he argued that since men will not read women's magazines (like Ismat), in order to reach men they have to establish a magazine only for men; ${ }^{75}$ and that Tamaddun will secure the rights of wives from husbands. ${ }^{76}$ By the turn of the twentieth century, however, women emerged as key participants in this conversation-as writers and editors.

Consider the conversation that ensues among the daughter of Maulvi Bashiruddin (often writers who practiced purdah did not reveal their first names and wrote as "daughter of" or "mother of"), Begum Saheba Rizvi, and Sayyida Asghari Begum that takes place across two issues of Ismat in 1911, where they respond to each other's views on education. The daughter of Maulvi Bashiruddin, in her article entitled "Talim niswan" (Women's Education), ${ }^{77}$ outlines the two sides of the debate on the issue of women's education: those who are against it and those who want the same education for women as that for men. The latter entails going to English schools and studying the curriculum determined by English standards. The author notes that since these discussions are about women, they, too, should pay attention to them. She discredits the first group by noting that since Prophet Muhammad said, "to acquire ilm (knowledge) is farz (duty) on all Muslim men and women," Muslims do not have to attend to those who argue against women's education. However, she then goes on to critique those who are in favor of English schools and provocatively asks: "What kind of education did the Prophet guide us to acquire?" To her, it is that which allows one to become a better Muslim. She then explains what this entails: women should learn to read and write in order to understand their $\operatorname{din}$ (faith); be able to send letters to their father, husband, and relatives; keep calculations about domestic chores (budget); and be able to address the everyday illnesses of their children and care for them. In short, this educated subject has knowledge of religion, elementary literacy skills, and can effectively manage her household. Any educative endeavors that do not yield such a transformation in women would be constituted as a failure. Indeed, this is precisely why the author claims that the books and novels that are taught in "English schools" are not useful as they divert women's attention to stories and fiction. Such knowledges do not fulfill the purpose of enabling women to improve their practice of religion or domestic management skills, and thus cannot be considered worthy. The author produces a dichotomy between English versus Islamic knowledges. While she advocates that women should get an education, English knowledges, often represented by novels and stories, are deemed unnecessary and 
even harmful. Readers will recall that this line of reasoning is very similar to that proposed by Ashraf Ali Thanawi.

In response to this article, Begum Saheba Rizvi wrote a clarification on behalf of those who supported women's education outside the zenana. ${ }^{78}$ She notes that advocates like her do not believe that girls should go to English schools but to schools organized and managed by Muslims. Giving her own example, she explains that her grandfather, who was active in the women's education movement, said that it was not appropriate for Muslim girls to attend English schools due to the teaching of Christianity. Rizvi notes that Muslim girls should only join Muslim schools. The author goes on to express her grievance at the current status of the Muslim quam and their lack of attention to women's education. She sees this as a departure from the past, when both men and women were educated, and women excelled at many endeavors. This reference to the past is significant because it was a rhetorical strategy used by many writers, including male writers discussed earlier in this chapter. Feature articles on the lives of Muslim women of the past-such as the wives of Prophet Muhammad as well as his daughter, Fatima-were written time and again in women's periodicals to inform the readership of the long tradition of women's learning in Islam. The preponderance of such articles signals an effort to reclaim education as legitimately Islamic. The authors believed that Muslim women of the past were indeed "educated," and hence proposed that it was possible to obtain an education without attending English schools or compromising one's traditions and norms. In asserting that Muslim women of the past were intellectually accomplished and practiced proper Islam, Ismati behnain forged this very possibility for themselves as well.

Rizvi, however, opposes the curriculum proposed by the daughter of Maulvi Bashiruddin by noting that more substantial education was required for women, which included chemistry, literature, geography, astronomy, and history, in addition to religion. Elementary knowledge of religion, which allowed one to only study a book or two translated into Urdu (as the daughter of Maulvi Bashiruddin had suggested) was not useful. Rizvi's calls are reminiscent of Mumtaz Ali and the Aga Khan, who, too, called for broad-based education for girls. She further observes that the fact that girls do not have relevant reading materials (and hence read novels and stories that do not align with their culture and customs) is a result of men's lack of effort in making such literatures available to women, as well as the widespread support for only elementary education of women. The author concludes by calling for the establishment of an Islamic (Islami) girls' school.

In the same issue of Ismat, Sayyida Asghari Begum also responded to the article written by the daughter of Maulvi Bashiruddin. She notes that the restriction of women's education to only the study of hadith and fiqh was limiting. She explains that Muslim women in the past had been extremely accomplished and cites the example of the daughter of Prophet Muhammad, Fatima, as being a renowned poet. At the same time, she agrees with the daughter of Maulvi Bashiruddin, that 
"the company of missionary ladies is poisonous for our uneducated women." 79 She proposes that if women were to set aside some of their earnings for the establishment of Islami schools and colleges then it would not be necessary for them to go to English schools and colleges, or read inappropriate texts. She calls on male reformers to attend to women's education and raise funds as they had been doing for the establishment of the Muhammedan Anglo-Oriental College.

I have included this brief exchange among three women across two issues of Ismat to illustrate the vibrant conversations that were taking place among women on the topic of women's education. These dialogues resist the impression that the discourse on women's education was only shaped by men. While it is true that women called on men to attend to their needs, it is also significant to acknowledge women's own contributions to this debate. Importantly, this conversation exemplifies three different but overlapping visions of an educated subject. The daughter of Maulvi Bashiruddin sees the purpose of education as producing proper Muslims and, hence, emphasizes the acquisition of religious knowledges. Her proposal excludes the study of the English language and English literatures, as she does not envision such subjects to play a critical role in women's everyday lives. Both Rizvi and Asghari Begum call for a broad-based education that includes the study of the sciences, because they believe that if Muslim women were to reacquire their prominent positions in the world (similar to that held by Muslim women of the past, as they imagined) then they would have to partake in all available knowledges. However, they do not see English schools as the ideal location for education, as such spaces introduced ideas that were "poisonous." These fears were often associated with the preaching of Christianity in English schools as well as the study of what they considered as irrelevant literary texts written by western authors. All three writers draw on the discourse on religion to legitimize their stances. What we have then is a glimpse into ashraf women's negotiations around education, which also reveals the kinds of roles that they envisioned for themselves and other women of their social class.

The tensions across these different articulations of appropriate knowledges for women are also a reflection of the opportunities for livelihood that were available to women of different social classes. This becomes clearer in Muhammadi Begum's (1878-1908) didactic novels.

\section{CURRICULUM FOR SHARIF DAUGHTERS}

Muhammadi Begum's Sughar beti, published in 1905, is a meticulous and detailed account of how young girls should comport themselves in their everyday lives. Begum decided to write this text after completing Rafiq uroos (Friend of the Bride), which was aimed at married girls ("biyahi larkiyoon"). ${ }^{80}$ She wrote Sughar beti for "unmarried, young-aged, girls" ("kuwari, kam umer larkiyoon"). ${ }^{81}$ The author paints a picture of a young girl living in a sharif household and how she 


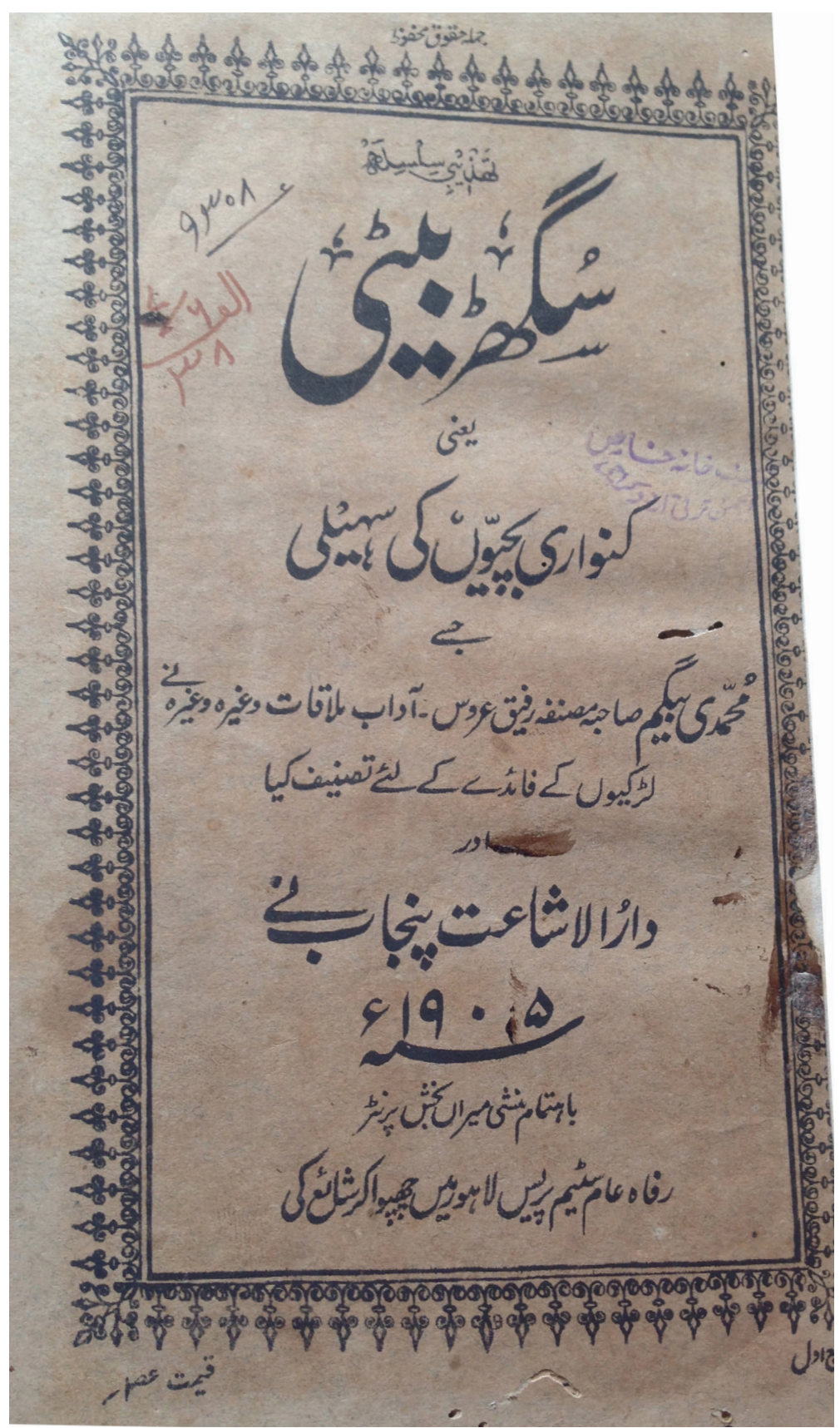

FIGURE 1. Cover page of Muhammadi Begum's Sughar beti. 
should operate in all aspects of her life so that she excels in both din (faith) and duniya (world). The text's tone is that of a familiar friend, as the author addresses the reader using personal pronouns (such as tum, "you"), which helps to achieve a sense of intimacy. It also marks the reader as a sharif girl and the author as her well-wisher, an advisor. Muhammadi Begum shares several personal anecdotes to further establish a sense of kinship with the reader. ${ }^{82}$ In one instance, she mentions an event from when she was sixteen years old and wanted to have a new set of clothes. The fabric the shopkeeper sent over to her, however, was see-through. She returned it, asking for thicker cloth to maintain her haya (shame). Much like Mirat-ul-uroos, Sughar beti sets out to be a comprehensive advice text for young girls and, in this way, is useful to explore the construction of the ideal sharif daughter-subject.

The text includes the story of the "ignorant girl" (ghafil larki) against whom the ideal girl becomes legible. The ghafil larki is careless, impulsive, and wasteful. She misses her morning prayers, forgets to pick up her jewelry after washing herself, fails in examinations, drops hot food on herself, and burns herself. She creates difficulties for herself and her mother. She repeatedly fails to perform an educated subjectivity not only due to her inability to read or write but also due to her failure to be a thoughtful member of the family. Ideal girlhood, in this case, is accomplished in the context of the patriarchal family and falling short of one's responsibilities in that domain marks one as a failure.

In contrast, the ideal girl possesses an awareness of God, respects and loves her parents, elders, and teachers, and successfully performs her myriad roles within the patriarchal family. Muhammadi Begum provides detailed advice on how to perform this subjectivity of the good daughter (beti): "do not annoy your parents to fulfill your desires for play and asaish (luxury)"; 83 "girls should help their mothers with household chores"; "my dear girls, if you are clever and are able to work, then you should provide rest to your mothers. Take over the work they are doing." ${ }_{5}$ The author goes on to explain how to sit in the presence of adults, particularly, fathers; ${ }^{86}$ to put on orthni (covering) when brothers or father enter the zenana; and, to respect them (tazeem). The author also discusses personal hygiene, dress, and play. She advises girls to learn housekeeping (khana-dari) from their mothers but to also keep an eye out for books and other resources from where they can learn how to manage their future households. In fact, Muhammadi Begum herself wrote a book entitled, Khana-dari (Housekeeping).

The ideal girl is also not enticed by English norms. Muhammadi Begum advises girls to not take up the English dress because those who do are laughed upon by both their own quam and the English:" "we should continue our quami dress and if there are any faults we should correct them." ${ }^{88}$ Here quam signifies the specific religious, class, and ethnic community that made up the ashraf. Muhammadi Begum urges girls to try to learn how to read and write. She argues that these skills are important so that girls can communicate with their parents and siblings after 
marriage and are not dependent on others. Significantly, as Muslims, she deems it incumbent upon girls to learn the Quran and know its meaning. She also advises girls to improve their writing skills, because "good writing can become a source of income for poor girls." However, literacy appears as only one component of a girl's broad-based education. Other elements include proper disposition and etiquette, as well as household management.

Another key aspect of education for Begum is learning the hunar (skills) of sewing, embroidery, and cooking. ${ }^{89}$ The author emphasizes that both rich and poor girls should learn hunar because in times of difficulty one can meet their requirements with hunar. She argues that it is all the more important for women to know hunar, because if bad circumstances befall a man, he can always find manual labor (mazdoori) but such kinds of work are not available for women: "hunar is a blessing and all humans should seek it all their lives." ${ }^{\circ}$ The author also likens hunar to wealth, which cannot be stolen. While women's monetary contribution to the household was still a nascent idea and did not enjoy wide support-after all, working for money was not a practice that sharif women undertook-given the changing economic contexts of the ashraf, these expectations had to be revised. Muhammadi Begum appears to be playing a role in destigmatizing both work undertaken at home so that families did not have to hire servants as well as income generation by sharif women. Her novel Sharif beti is a clear example of this rethinking of ashraf women's roles in the home and beyond.

In Sharif beti, Muhammadi Begum sets out to address girls from low-income but respectable families. Published first in 1908, the book was republished in 1912 and then again in 1918. Sharif beti is the story of a ten- or eleven-year-old girl, Sharif-un-Nissa-also called Sharifun, whose family descends into poverty after her father's death and her mother's subsequent illness. The text traces Sharifun's early life to show how she overcomes myriad forms of hardships while forging new pathways toward respectability. This text was quite successful, with a thousand copies printed in 1908, a second edition of another thousand copies in 1912, and then a similar number in 1918. Sharifun is parhi likhi (someone who can read and write), knows the Quran, was taught Urdu and Farsi by her younger brothers, and has the hunar of sewing and cooking. These knowledges, taken as a whole, mark her as a subject who is intelligent, thoughtful, and resourceful. The text illuminates Sharifun's resilience and work ethic in sustaining her mother and younger brothers over several years. In addition to taking up the work of sewing, Sharifun eventually opens a madrasa for girls at home, and becomes financially secure.

The text seeks to reform ideas around paid work, gender, and respectability. There is a strong thematic focus in the book on destigmatizing paid work for women and girls, and marking those girls who engage in such work as respectable. It seems that Muhammadi Begum believes that Sharifun's subject position will become commonplace in coming years as Muslim households in Lahore specifically, and North India more broadly, cope with the changing economic and social 


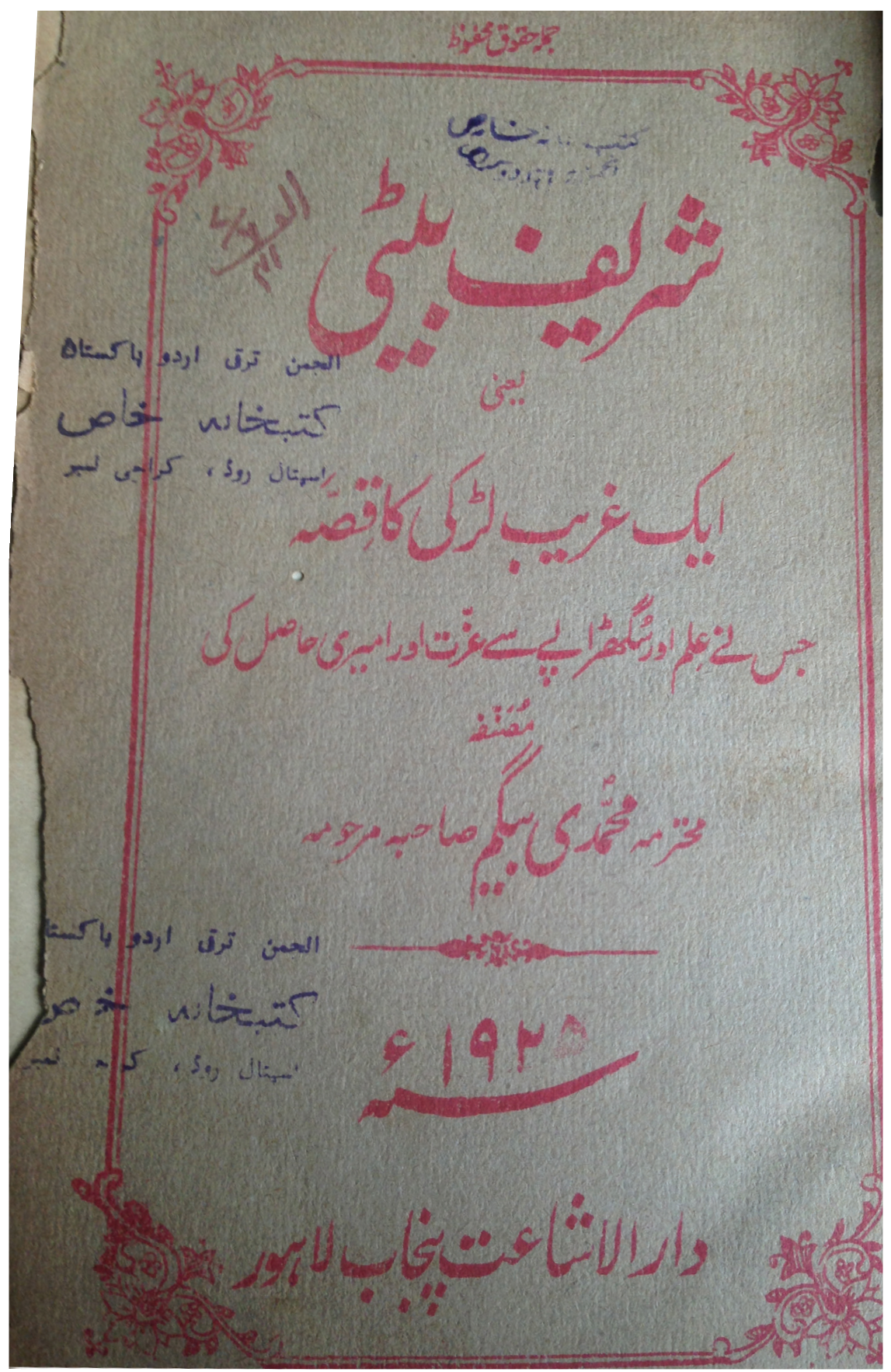

FIGURE 2. Cover page of Muhammadi Begum's Sharif beti. 
environment. She thus argues that to work for pay is not an aeb (fault). Even so, there exists a strong undercurrent in the text whereby it is assumed that working for money should be reserved only for dire situations. Such exceptions show Muhammadi Begum's struggle with competing requirements of respectability and economic precarity.

For instance, we learn that since respectable women did not work, after the death of her husband, Sharifun's mother goes to great pains to ensure that Aman-ma (their servant who used to bring them piecemeal work) did not disclose their identity to any potential clients. Likewise, when her mother falls ill and Sharifun has to take over the management of her household, she, too, privileges secrecy. She even declines offers for tutoring girls in the neighborhood in order to protect her identity. Later in the novel, we observe that Aman-ma convinces Sharifun to take up teaching in order to provide for herself and her brothers. Furthermore, Begum marks only particular kinds of work-where requirements of purdah could be maintained such as sewing, teaching, and nursing at home-as acceptable. This selective sanctioning continues to reproduce class boundaries because it was often not possible for lower-class women to maintain seclusion.

Muhammadi Begum's attempts at figuring out ways to reproduce sharafat during these economically constrained times are visible in her text, Hayat-e-Ashraf. In it she traces the life of another sharif woman who has to leave the zenana to earn an income upon the death of her husband, and is successful in doing so while maintaining pur$d a h$. One could also read the novel as showing how a woman significantly stretched the limits of acceptable practices of purdah when her circumstances demanded it.

\section{Hayat-e-Ashraf}

Hayat-e-Ashraf was compiled by Muhammadi Begum and includes not only Muhammadi Begum's account of Ashraf-un-Nissa's (d. 1903) life, but also articles written by Bibi Ashraf herself, in which she describes her efforts to learn reading and writing, ${ }^{91}$ as well as the writings of Bibi Ashraf's daughter, Jafari Begum. Hayat$e$-Ashraf, then, is a piece of writing that bears the imprint of three different women. I therefore view it as a palimpsest, layered with multiple performances of educated selves. While these different kinds of writings-letters, poems, articles-have a life of their own, they are also brought together by Muhammadi Begum, who complied them as a didactic text for young girls' reading pleasure. In the context of this chapter, Hayat-e-Ashraf can be viewed as a case study-the specificities of Bibi Ashraf's life circumstances, her efforts to educate herself, her desire to maintain purdah, her struggle for economic survival, and her staunch religious practices, are all aspects that help to ground some of the trends that I have discussed thus far. Furthermore, the text also helps to frame discussions about women's mobility and spaces for education, which will be discussed next.

Bibi Ashraf was born in 1840 in a Shia Muslim family in Bahnera, a small community in Bijnor, Uttar Pradesh. Hayat-e-Ashraftraces her life from birth to death; 
however, as noted earlier, Muhammadi Begum chooses to include Bibi Ashraf's own words to elaborate some periods of her life. In particular, Muhammadi Begum reproduces two articles written by Bibi Ashraf, which were first published in Tehzib-e-Niswan in 1899, sketching her childhood. These first-person accounts provide us a glimpse into prevailing attitudes about women's reading and writing at least within the ashraf families of North India. Instead of finding the oppressed, silenced, victimized Muslim girl, we find a resourceful Ashraf, who through the help of her grandmother, encouragement of her father, and creative maneuverings, overcomes the hindrances of her mother's death, lack of teachers, as well as obstacles created by an uncle and an aunt, to learn how to read and write. Significantly, Bibi's Ashraf's writings give us insights into the functioning of maktabs for girls and the kind of curriculum available to them. The key hindrances for women's education in Hayat-e-Ashraf seems to be limited support from some (not all) members of the family, lack of qualified female teachers, and insufficient availability of literature/reading materials. Yet, the text is replete with examples of a thriving culture of learning among girls. Indeed, as I will elaborate below, Jafari Begum writes a poem expressing her sadness at the conclusion of her madrasa education.

Bibi Ashraf informs us that girls in her biradari (extended family or tribe) were taught to read for a long time, although teaching of writing had been opposed. Her own mother knew how to read the Quran and Urdu books, and it was expected that she, too, would obtain such an education. She notes that her grandfather had hired a female teacher for ten rupees per month, plus food and clothing. The teacher taught the six girls in Bibi Ashraf's household, but over time twenty to twenty-five girls from the neighborhood joined them. Hence, it became a kind of maktab (small school). ${ }^{92}$ In addition to reading the Quran, the students learned how to cook and sew. ${ }^{93}$ The teacher (who was also of similar social status-being a sharif pathan), however, did not know the Urdu language, and even after searching for an Urdu teacher, one could not be found. ${ }^{94}$

Soon, the teacher remarried-a practice (widow remarriage) that was not deemed acceptable in sharif households at the time. ${ }^{95}$ This was read as a personal insult by Bibi Ashraf's grandfather, who then disallowed the teacher to teach his female relations. He was no longer willing to admit a stranger into his household. Bibi Ashraf and the other girls thus were left without a teacher. She recalls that many of the girls continued to learn from their mothers; at that time, however, her own mother fell sick, and soon passed away: "my mother was more sad about my not being able to study than her own illness." 96 This sentiment again points to the desire for learning that women of different generations seemed to have had, and the ability of older women to teach their children. Bibi Ashraf's mother was a marsiya khwan (a reciter of Shia elegies that commemorate the martyrdom of the grandson of Prophet Muhammad, who was a Shia imam)_pointing to women's 
rich oral cultures. At the time of her mother's death, Bibi Ashraf had completed seven out of thirty volumes of the Quran, and upon her grandmother's urging, ${ }^{97}$ set out to complete the rest on her own. While there were many positive role models in Bibi Ashraf's life who urged her to read and write, we also learn about her uncle and aunt, as well as "other ladies" who discouraged her. ${ }^{98}$ It is precisely due to this reason that she had to devise alternate, creative ways to continue her study, this time to learn the Urdu language.

Bibi Ashraf decided to obtain devotional texts from her relatives and used to sneak up to the roof during the afternoons, when others were sleeping, to copy the texts. ${ }^{99}$ She creatively used everyday materials, such as grill ash, to produce ink, the lid of the water pot as a container for the ink, and twigs from the broom to write with. She tricked her grandmother into securing paper for her. Bibi Ashraf was delighted to be able to copy these texts-she recalls: "The happiness of that time is beyond words." when she encountered a teacher in the most unexpected of circumstances. As she recalls, a younger male relation once asked her to help him with Quran lessons. While helping him, she found out that he knew the Urdu language and asked him to teach her. He refused, noting that he did not have the time and that she would not understand the book anyway. ${ }^{101}$ At that point, Bibi Ashraf threatened him: "if you don't teach me, I will not teach you either." ${ }^{102}$ This convinced the cousin, who began teaching her Urdu. He was, however, soon sent off to Delhi to study but Bibi Ashraf persisted and continued to draw on what she had learned to complete the Urdu language book on her own. She became so adept at Urdu that other women asked her to write letters on their behalf. ${ }^{103}$ During the conflicts of 1857 , her father-who worked in Delhi-could neither visit them nor write to them for a year and half. When peace was restored, her grandmother asked her uncle to write a letter on their behalf. Bibi Ashraf, however, also wrote a letter to him. Upon reading that letter, her father was extremely pleased-so much so that he sent a reward for her and praised the letter for elaborating not only the conditions of the family but also other events: "This letter gave the pleasure of reading a newspaper and history. I read it once every day." ${ }^{104}$ Needless to add, Bibi Ashraf's paternal uncle was not happy.

I have traced Bibi Ashraf's experiences of learning and reactions from family members to highlight the specificity of girls' efforts to learn. On one hand, we have the figures of the mother, grandmother, father, and grandfather, who encouraged her to varying degrees, and on the other hand, the paternal uncle and aunt, who did not. These specific stories contradict sweeping interpretations about Muslim women and their families of the past. This does not mean that women did not have difficulties. Boys and men had far more opportunities than women: Bibi Ashraf's father was educated and worked as a lawyer; her husband was afforded an education at the Delhi College that enabled him to become an assistant professor of 
Arabic and Persian at the Government College in Lahore; even the young male cousin who taught her Urdu was sent off to Delhi for education. What is interesting to note, however, is that there were figures who supported women's education, and that women creatively navigated other restrains.

It is this education that served Bibi Ashraf well upon the death of her husband when she had to provide for herself, her children, and four to five young relatives who were part of her household. Early on, she drew on her skills of sewing (including lacework) to sustain her household; ${ }^{105}$ later, she took up a teaching job at a semi-government school in Lahore, Victoria Girls School, where she eventually became the head teacher and continued to work until her death in 1903. One of the key storylines in the text is that of Bibi Ashraf's ability to live respectably by drawing on her education and not compromising on religious practices and social norms, especially purdah.

Muhammadi Begum allocates significant space in the text to note that even though Bibi Ashraf worked in a school, she maintained the norms of purdah. Bibi Ashraf also ensured that proper arrangements for purdah were made for her students in the classrooms, ${ }^{106}$ as well as during pick-up and drop-off (in the form of a doli-a mode of transportation for women that was covered to ensure that outsiders could not see the passengers inside). Her tenure at the school proved so successful that the school's reputation went from being one where sharif families would not send their girls to a school that now required seven dolis to transport sharif girls. ${ }^{107}$ Relatedly, we also find recurring mentions of Bibi Ashraf's devotion to her Shia religious practices. She organized majalis (religious gatherings) every Muharram, was regular in fasting and prayers, ${ }^{108}$ and distributed food to poor women. Bibi Ashraf also had excellent domestic management skills, which included living within her means, keeping a clean house, and being adept at cooking and sewing. This discursive representation of Bibi Ashraf serves the function of illuminating for the reader what an educated Muslim female subject could look like. The areas that Muhammadi Begum chooses to highlight-practice of purdah, performance of religious rituals, and khana-dari-were some of the prominent issues under discussion during that time as sharif families were concerned about the changes that education might bring about in the lives of their womenfolk. An ideal educated woman then was pious, an expert domestic manager, and could make a living if unfortunate circumstances befell her without seriously threatening the prevailing norms of her social class.

While Bibi Ashraf was able to perform this womanhood, there was less agreement on whether it was a real possibility for the majority of Indian Musalman women. Some reformers believed that women and girls should be able to leave the zenana to attend schools, either in the neighborhoods or even English schools; others saw the space outside the zenana as corrupting and therefore, a threat to familial respectability. Either way, ashraf women's movement in public spaces was undergoing negotiation. 
In the zenana, ashraf women enjoyed relative freedom from the male gaze. This allowed for contact with women across socioeconomic classes and provided secrecy to some extent. In these spaces women were "in charge" of many things, including arranging marriages, prescribing the rituals and etiquettes around birth, visiting elders, and organizing feasts. ${ }^{109}$ Women formed friendships and provided each other with support. For some ashraf women, as Bibi Ashraf's story shows, the zenana also was a place of learning. Girls often studied with tutors arranged for them in their homes or at their friends' homes. In Hayat-e-Ashraf, Muhammadi Begum reproduces some letters and poems written by Bibi Ashraf's daughter, Jafari Begum. One such poem, written upon the conclusion of Jafari Begum's time at the girls' madrasa, gives us a glimpse into the solidarity that girls experienced in such environments.

In the poem Jafari Begum calls her classmates hamjholiyan (friends) and behnain (sisters). ${ }^{110}$ She recalls the different kinds of activities that they undertook, from poring over maps and copying texts to learning to cook and sew. We get a sense of intense friendship among the girls; for instance, whenever Jafari Begum had to take time off from the madrasa other girls complained that the place felt empty (sunsaan). ${ }^{111}$ The poet also expresses nostalgia for the time she spent in the madrasa with her friends. ${ }^{112}$ Similarly, Bibi Ashraf notes how her eagerness to learn Urdu was the result of the time she spent in such spaces. When she was young she would observe other women read aloud from books during the majlis held every Thursday and during the month of Muharram: "all women from the kunba (extended family) knew Urdu very well." ${ }^{113}$ It was in such gatherings that the desire to learn the language sparked in Bibi Ashraf. In fact, it was also women from this broader biradari (tribe) who lent her the books of devotional literature that she would sneak up to the roof and copy.

Over time, however, both the colonial officers as well as Muslim reformers became suspicious of the zenana. Hidden from the male gaze, the zenana had allowed princely women to engage in politics while avoiding surveillance from British administrators. ${ }^{114}$ As Barbara Ramusack notes: "Since the British did not have direct access to the zenana or women's quarters, they were particularly anxious to reduce the influence of Indian women, whom they stereotyped as superstitious and of doubtful morality. Here the British conflated their Oriental concepts of the exoticism of Asian women, especially an uncontrolled sexuality and lack of intelligence, with British disdain for alternative sources of identity for young princes." ${ }^{15}$

Likewise, Muslim reformers, such as Thanawi, while advocating the practices of seclusion and purdah, had embarked on an effort to reform the zenana by installing men in charge. We observe this gradual transformation of the zenana in Mirat-ul-uroos, where Asghari constantly looks to her father, Durandesh Khan, for guidance. Durandesh Khan had sent her a letter upon her marriage, which 
included instructions on how she should conduct herself. She read the letter at least once a day, even if it was not necessary. When in need of advice, Asghari often wrote to her male relations to come to her rescue. In other words, it was men who prescribed the appropriate ways of managing the household, and women implemented their visions.

This reconfiguration of women's spaces is not unique to colonial India. Afsaneh Najmabadi observes a reconstitution of women's spaces in Iran as well, where calls for greater participation of women in public spaces decreased the privileges that they had enjoyed in homosocial spaces. ${ }^{116}$ Likewise, Lila Abu-Lughod critiques the elite Egyptian reformer Qasim Amin's calls for educating elite women and girls to improve their domestic management skills as another effort to "impose on women a new form of industriousness and new standards of household work that are more demanding of their time, keeping them bound to the home rather than permitting them time to visit." ${ }^{117}$ The anxieties around women meeting each other emerged in the context of colonial India as well. The ideal sharif woman did not engage in frivolous relations with lower-class women, as is clearly visible in Miratul-uroos. Similarly, Muhammadi Begum's protagonist in Sharif beti, Sharifun, and her mother take care not to disclose their financial difficulties to their neighbors.

This suspicion of women's activities and cross-class exposure also had an impact on the debate around ideal spaces for women's education. Could women leave the zenana to attend English schools? Islamic (Islami) schools? Neighborhood (mohalla) schools? What would be the implications of such movements on the practices of purdah? How would class distinctions be maintained? After all, it was only ajlaf women who moved extensively in the public spaces. Indeed, as the president of the Muhammadan Education Conference, Mamtajul Mulk Khalifa Sayyid Muhammad Hussain of Patiala, noted in 1905, "while all educated families agreed on the importance of educating girls, there were still differences in how and where that education should be given."118

Mrs. Abdullah, the coeditor of Khatun, was acutely aware of such anxieties and their implications for women's education. During the inaugural Ladies Conference in December 1905, she made a speech in which she noted that those who were against women's education often saw women's mil jhol (interactions) with fear. ${ }^{119}$ They dreaded that their daughters and daughters-in-law, if educated, would become like the women in America and Europe, whom they viewed with suspicion. However, Mrs. Abdullah assured the audience that Muslim women in Turkey and Egypt were also educated and continued to meet with each other, and had not engaged in any offensive habits (kharabiyan) — after all "why would kharabiyan emerge when sharif women are meeting together?" She argued that "men have extended the injunctions for hijab and purdah to call for restrictions on women's movements; however, that is changing as some men see such rituals as excessive." She went on to observe that there were also women who believed that not meeting other women (mil jhol) preserved their sharafat- "women believe that sharafat 
is within the four walls of their homes and people outside it are not sharif and, hence, do not deserve to be engaged." However, Mrs. Abdullah proposed that education would bring about a change in such forms of thinking. In other words, education would reform Muslims so that institutions such as public schools, too, could emerge as viable spaces for respectability. Mrs. Abdullah sought to advance women's education by allaying fears that entering new educative spaces or leaving the zenana might lead to corruption in women. She articulated activists (much like herself) who were already in these spaces as sharif. This move was crucial because Mrs. Abdullah was part of the group that called for separate schools for girls. In fact, she and her husband established a Normal School in 1906, which later also included a hostel. She and her sister dedicated much of their lives to these schools. Other women, such as the Fairzi sisters and the Begum of Bhopal, were also active in establishing and/or raising funds for such institutions. ${ }^{120}$ Redefining the spatialities of sharafat in this manner was significant in order to encourage girls' participation in such schools.

It is in this environment that Muslim reformers became particularly interested in establishing schools that represented their values. During the meetings of the All India Muhammadan Educational Conference, a forum established by Sir Syed Ahmed Khan in 1886, some leaders proposed that a more concerted effort should be made to establish institutions for women's education. In the third annual meeting of the conference in 1888, it was resolved that Muslims should set up zenana maktab (female schools) "strictly in conformity with the traditions and respect of the respectable and well-bred Mohammadans, and in accordance with their religious injunctions." ${ }^{121}$ While Sir Syed rejected these proposals in 1889 and again in 1891, after his death in 1899 a number of leaders in the conference marked it as a priority. That year the conference passed a resolution for setting up a girls' school in the capital of every province, and the next year called for preparing appropriate books for Muslim girls. The 1905 Muhammadan Education Conference was another key platform where different visions for women's education were debated and discussed. Here, a major proposal was the establishment of a boarding school for girls. In the presidential address at the conference, Mamtajul Mulk noted that various groups had divergent preferences for how girls should be educated and called on the attendees to work on these multiple pathways. ${ }^{122}$ Those who were willing to give education privately should do so, and those who could create madrasas should do that as well. Hence, there was a recognition and acceptance of multiple points of view on the issue, which took into account preferences that reflected social class interests as well.

Many social reformers set out to establish schools in the late nineteenth and early twentieth centuries. These efforts included Munshi Muhammad Qasim's school in Bangalore, established in 1867; Amina Khatoon's school in Baroda, in 1895; the Aga Khan III's effort to establish schools for girls, in 1905, in Gwader and Mundra; the Aligarh Zenana Madrasa, established by Shaikh Abdullah and Wahid 


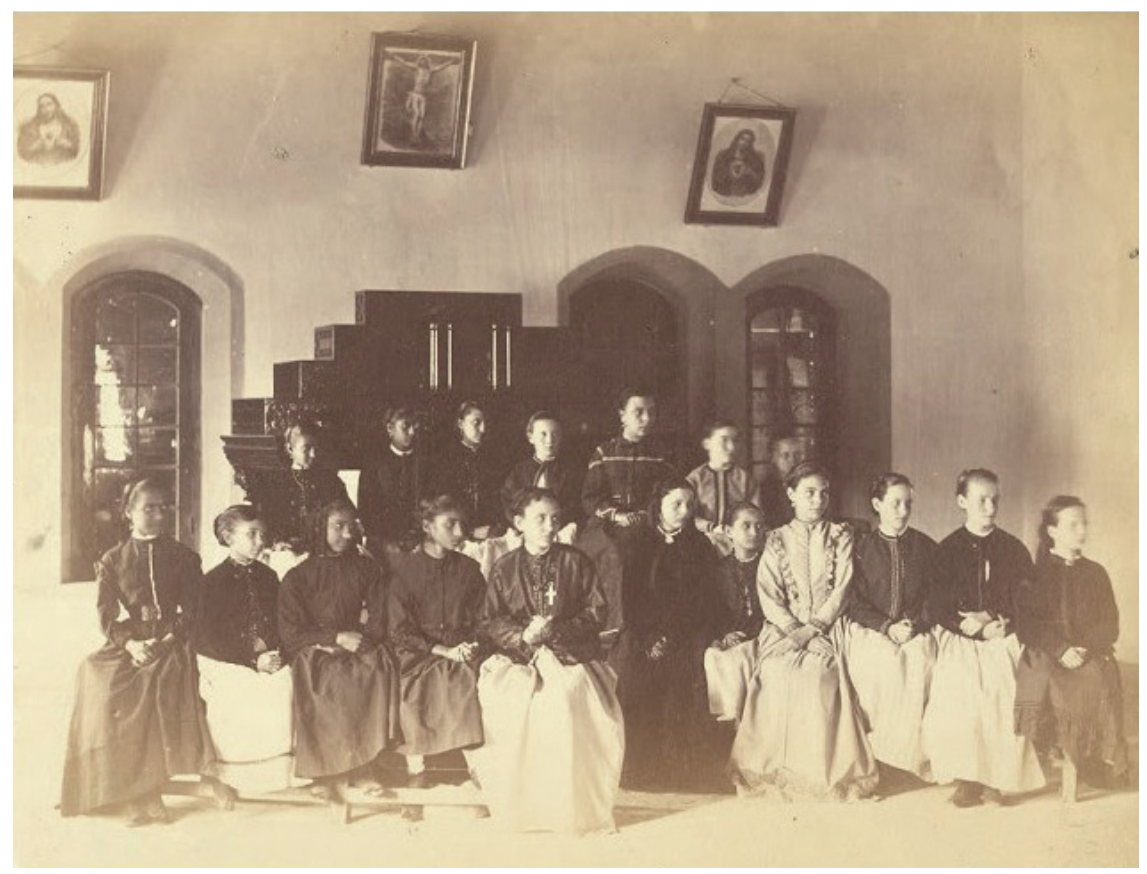

FIGURE 3. Girls at a convent school, ca. 1873. (Figs. 3-6 retrieved from Native Pakistan website, http://nativepakistan.com/photos-of-karachi [accessed January 23, 2018]).

Jahan in 1906; and Rokeya Hossain's school in Calcutta in 1911, among others. Such schools were often supported by elite Muslims such as the Begum of Bhopal and the numerous other Muslim women who sent donations to Shaikh Abdullah and whose names appeared in the issues of Khatun, ${ }^{123}$ through grant-in-aid awarded by the British administration, and/or funds raised within Muslims communities through farmaish (exhibitions) and meena bazaars (women's shopping spaces). ${ }^{124}$ Christian missionaries, who also had zenana-visitation programs in place since the early nineteenth century, primarily ran the government schools.

Figures 3 through 6 depict the different kinds of schools operative at the turn of the twentieth century. Even a cursory comparison of the photographs gives us a glimpse into the anxieties around the changes that English education might have introduced. In figure 3, for instance, girls who attend Christian missionary schools are donning English/western clothes and there are paintings of Jesus and Mary on the wall. In comparison, girls in figure 4 seek to maintain purdah, are learning the Urdu alphabet, and in addition to the female ustaani, there also appears to be a male guardian present. Likewise, in figure 5, girls appear to be wearing dresses, which later became a target of admonishment (as the next chapter will show). 


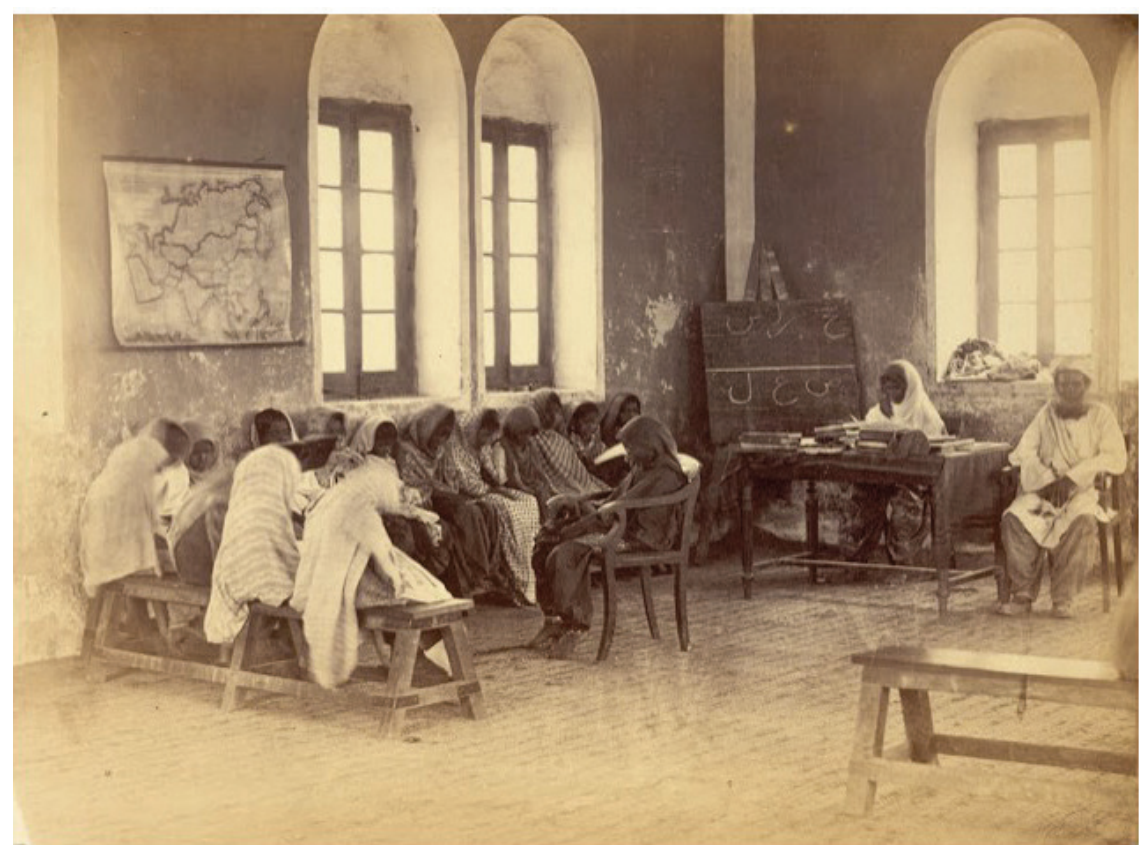

FIGURE 4. A vernacular girls' school, ca. 1873.

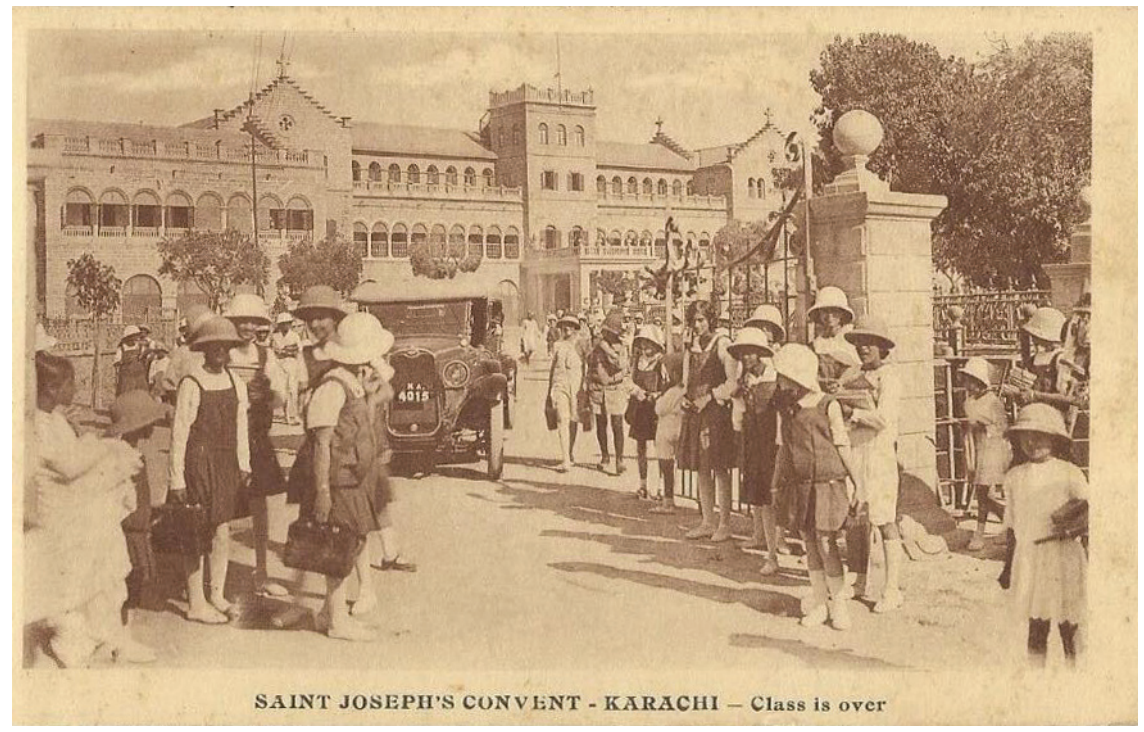

FIGURE 5. St. Joseph's Convent School for Girls, established in 1862. 


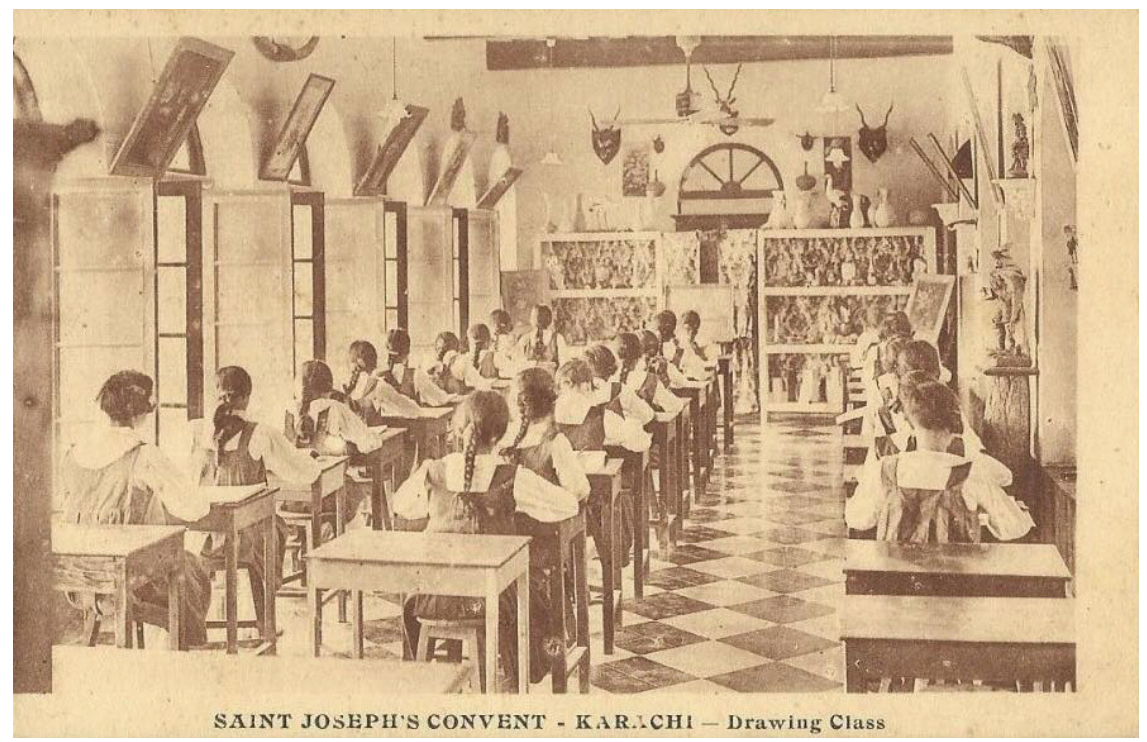

FIGURE 6. A drawing class at St. Joseph's Convent School for Girls.

A large number of purdah-observing women did not want to send their daughters to government schools. Hence, during the Ladies Conference of 1905, a key resolution was passed to establish a Normal School in Aligarh for training teachers who would teach sharif girls at home. ${ }^{125}$ This demand for teachers came from elite Muslims, and fundraising efforts, too, drew on the support of these Muslims. Such efforts and activism for women's education continued and strengthened during the early decades of the twentieth century as a greater number of associations advocating for women's education were established. For example, Anjuman-Islamia (Association of Islam) was formed in 1876 and set up a girls' primary and secondary school; Anjuman-i-Muslim Khawateen (Association of Muslim Women) was established at Nagpur; and, in 1908, Sir Muhammad Shafi founded Anjuman-iKhawateen-i-Islam (Association of Islamic Women) in Lahore with Begum Shafi as the president.

While in the discussion thus far we observe a consensus around the need for women's education and an effort to devise multiple avenues for women to obtain education, this was still an elite phenomenon. Literacy among women was below one percent, ${ }^{126}$ and according to the reports collected by the Muhammadan Educational Conference, female education was the lowest priority of the British government. For example, in an editorial in Khatun in $1906,{ }^{127}$ we learn about the details of a committee set up by the British on women's education. After six months, the committee submitted a report to the government noting that while 
the government had promised in August 1905 to reserve budget for women's education, it had not yet done so by the following year. The editor, Shaikh Abdullah, expressed his disappointment at this inaction by the government. He noted that even after recognizing its responsibility towards girls' education the government did not do anything: "Until now it was argued that Hindustani people do not want to educate their women, and that's why the government did not want to raise the issue. However, that is no longer the case. Thousands of people want to educate their daughters and sisters, then why is the government not helping and leading us and is being lazy? A cultured government no longer has any excuse." ${ }^{128}$

\section{ATTACHING RESPECTABILITY TO WOMEN'S PERFORMANCES}

South Asian historian Sanjay Seth provocatively asks that if by the turn of the twentieth century there was an agreement around the need for educating women, why then was there still so much discussion about this topic? ${ }^{129}$ In this chapter I have shown that women's education was a topic of extensive discussion because it was linked with notions of familial sharafat. While there was an agreement that women made the ideal site to display familial social status, there was less agreement on which kinds of performances of women would signal this sharafat. It is against this background that different articulations about women's knowledges and spaces for education traced in this chapter become meaningful. They point to an effort by Muslim reformers, both men and women, to make good middle-class wives and mothers, as well as potential future workers. It is an effort that transformed women's homosocial spaces, which had encouraged cross-class contact and alliances as well as kin-based activities, into a space where men were increasingly in charge. Eventually the zenana would be replaced by the nuclear family, under the control of the father/husband.

These trends crystalized group boundaries along class lines. Whereas in the past, elite as well as poor women were considered the weaker, corruptible sex, and hence excluded from the domains of men, now, ashraf women were able to participate in at least some public spaces and knowledges previously restricted only to men. Lower-class women still could not access the kinds of educational opportunities that have been reviewed in this chapter and constituted the other of sharif women. In other words, women from the nobility and new ashraf social classes were able to reinscribe their sharif status through education, but women from lower-income classes who were omitted from previous ethnic/class-based definitions of sharafat continued to be excluded. Indeed, in Nazir Ahmed's Miratul-uroos, while both Akbari and character of the hajjan appear as subjects whose conduct does not conform to the expectations of ideal womanhood, only Akbari is portrayed as a salvageable subject (as she later reforms her ways). The hajjan who belongs to the lower class continues to appear as a failed subject. Likewise, the 
ghafil larki (ignorant girl) of Muhammadi Begum's Sughar beti, too, can be rescued via education because after all she is still a sharif larki.

In the next chapter, we will observe that the tension around appropriate knowledges for women continues to persist in post-independence Pakistan, where those who were educated in convent/missionary schools come to be marked as failed subjects. There is a resounding call for the newly established nation to produce a new kind of educated citizen-subject, one who is grounded in local languages and religion, and will participate in the development of Pakistan. The discourse on sharafat which helped define ideal orientations to self, others, family, and religion, now is linked with the discourse on ideal Pakistani citizen-workers, performing the same functions of defining orientations but now also including those toward the nation and waged work.

\section{Disaggregating the Girl/Woman}

Before moving on to the next chapter, I want to pause and note here that I read the turn of the twentieth century as a moment that launches the disaggregation of the category of the woman/girl. As noted in the first chapter, Ruby Lal has observed that while during the early decades of the nineteenth century we can detect a female figure engaged in playful activities who can be read as a "girl," this figure morphs over the course of the century into a composite of girl-child/woman. ${ }^{130}$ Girls come to be invoked primarily as future wives and future mothers. The texts that I have surveyed in this chapter from the turn of the twentieth century show instances where the girl-child/woman is articulated outside the discursive frames of future wife and future mother as well. Women's writings provide evidence of multiple and complex female figures: engaged in play (Sughar beti; Hayat-eAshraf), as students (Sharifun and her students; Akbari's students; Bibi Ashraf), and as contributors to household income (Sharifun). There appear subjects who are willing to travel and live in boarding schools to acquire an education, who are transforming the space of the home into a madrasa, and who decide to work in the public sphere as teachers, political activists, and editors. These subjects understand their circumstances and engage with them in a thoughtful manner. Their education often includes the study of the Quran, seminal texts in Arabic, Persian, and Urdu, and domestic management skills as well as skills that could potentially be monetized. They are economically dependent on their male relations but can put together a meager income in dire circumstances. In some cases (such as that of Bibi Ashraf), they may also be able to find employment within the colonial administration.

The archives explored in this chapter, thus, begin to add layers to the dominant characterizations of the girl-child/woman as a future mother and future wife. The Muslim girl-child/woman of the turn of the twentieth century is a future domestic manager, future mother, and future wife but also a student, traveler, editor, writer, and activist. Furthermore, as we move forward to the 1920 (a period not taken 
up in this book), periodicals such as Phul (first edition, 1910) and Bannat (first edition in 1927), and novels such as Musalman larkiyoon kay liyay (For Muslim Girls), published by Khuwaja Banoo Saheba in 1929, among others, specifically invoke terms such as larki and bachi in addition to the usual dominants terms of niswan and khatun that circulated in the nineteenth century. These texts, written for the girl's (larki) reading pleasure, to teach her elementary language skills and prepare her for married life, also bring into being these very subjects. Indeed, as the twentieth century progresses, we observe the consolidation of the category of "girl" as she becomes one of the most prominent sites of monitoring and regulation through the expansion of mass schooling. 